\title{
RASIONALITAS DAN EVALUASI PENETAPAN BEA KELUAR DALAM RANGKA MENDUKUNG KEBIJAKAN PENGELOLAAN MINERAL
}

\author{
The Rationale And Evaluation Of Export Tax To Promote Mineral Management Policy
}

\author{
M. Zainul Abidin \\ Kementerian Keuangan \\ Gedung Notohamiprodjo Lantai 6, Jl. Wahidin 1, Jakarta Pusat 10710 \\ E-mail: abidinmz@gmail.com \\ Dikirim: 13 Maret 2014; direvisi: 18 Maret 2014; disetujui: 12 Mei 2014
}

\begin{abstract}
Abstrak
Penelitian ini bertujuan untuk mengetahui urgensi penetapan Bea Keluar (BK) Mineral dalam Peraturan Menteri Keuangan Nomor 6/PMK.011/2014 (PMK 6/2014) guna mendukung kebijakan pengelolaan sumber daya mineral dalam Undang-Undang Nomor 4 Tahun 2009 (UU 4/2009), dan dampak PMK 6/2014 terhadap masyarakat, investor pertambangan dan pemerintah. Penelitian ini menggunakan pendekatan deskriptif kualitatif. Hasil penelitian menunjukkan bahwa penetapan BK mineral dalam PMK 6/2014 diperlukan guna memperkuat tujuan kebijakan pengelolaan mineral dalam UU 4/2009, khususnya dalam rangka menjamin manfaat pertambangan mineral secara berkelanjutan dan berwawasan lingkungan hidup, serta menjamin ketersediaan mineral untuk mendorong investasi baru dalam industri pengolahan mineral di dalam negeri. PMK 6/2014 telah berdampak pada penurunan volume ekspor mineral dan pelemahan aktivitas ekonomi di wilayah sekitar pertambangan sehingga, dalam jangka pendek, merugikan masyarakat sekitar tambang, investor, dan pemerintah. Namun, dalam jangka panjang, pengenaan BK dalam PMK 6/2014 dapat berdampak positif terhadap perekonomian nasional sepanjang tersedia industri pengolahan dan pemurnian mineral di dalam negeri.

Kata kunci: anggaran pendapatan dan belanja negara, bea keluar mineral, industri pengolahan mineral, investasi pertambangan, tenaga kerja.
\end{abstract}

\begin{abstract}
The aims of this research was observing mineral-export tax in The Regulation of the Minister of Finance Number 6 Year 2014 (PMK 6/2014) to promote mineral management policy in the Law Number 4 Year 2009 (4/2009), and the impact of PMK 6/2014 on society, government and mining investors. This study used a qualitative descriptive approach. The results showed that PMK 6/2014 necessary to strengthen the policy objectives of management of minerals in Law 4/2009, in particular in order to ensure the benefits of mineral mining in a sustainable and environmentally, as well as guarantee the availability of minerals as raw materials for domestic needs. In the short-run, the impact of mineral-export tax detrimental to surrounding communities, investors, and government. In the medium and long-run, the mineral-export tax can have a positive impact on the national economy if there are mineral processing and refining plants.

Keywords: labor, mineral export tax, mining investment, smelters, state budget.
\end{abstract}

\section{PENDAHULUAN}

Perekonomian Indonesia menunjukkan perkembangan positif. Selama kurun waktu 20092013, pertumbuhan ekonomi rata-rata mencapai $5,9 \%$ per tahun. Produk Domestik Bruto telah meningkat dari Rp4.954 triliun (tahun 2008) menjadi Rp9.084 triliun (2013) dan pendapatan per kapita tahun 2008 sebesar Rp21,3 juta menjadi Rp36,5 juta pada 2013 (BPS, 2009 \& 2014). Sementara itu, tingkat kemiskinan dan pengangguran dapat ditekan masing-masing pada level $11,37 \%$ dan $5,92 \%$. (www.presidenri.go.id, diakses 24 Juni 2014).

Salah satu pendorong pertumbuhan ekonomi Indonesia berasal dari aktivitas ekspor. Pada tahun 2013, aktivitas ekspor telah menyumbang kepada sumber pertumbuhan ekonomi sebesar 2,52\% (BPS, 2014). Salah satu sektor yang mendukung ekspor berasal dari sektor pertambangan mineral. Selain itu, kegiatan ekspor mineral telah memberikan sumbangan yang besar terhadap perekonomian nasional dan daerah dan menambah penerimaan negara.

Pasal 33 ayat 3 UUD 1945 menyatakan bahwa bumi dan air dan kekayaan alam yang terkandung di dalamnya dikuasai oleh negara dan dipergunakan untuk sebesar-besar kemakmuran rakyat. Hal ini menunjukkan bahwa bahan mineral di bumi Indonesia merupakan sumber daya alam yang bermakna strategis sehingga perlu dikelola secara optimal guna meningkatkan taraf hidup masyarakat. Guna memberikan landasan hukum yang kuat dalam pengelolaan sumber daya alam, Pemerintah telah menerbitkan Undang-undang Nomor 4 Tahun 2009 tentang Pertambangan Mineral dan Batubara (UU 4/2009).

Pasal 103 dan 107 UU 4/2009 mengamanatkan para pelaku usaha pertambangan melakukan kegiatan 
Tabel 1. Penerimaan Negara dari Pertambangan

\begin{tabular}{lccccc}
\hline Keterangan & 2009 & 2010 & 2011 & $2012^{*}$ & $2013^{*}$ \\
\hline PNBP (triliun rupiah) & 15,3 & 18,6 & 24,7 & 27,2 & 29,9 \\
Pajak (triliun rupiah) & 36,1 & 48,3 & 55,0 & 81,7 & 89,9 \\
Total & 51,4 & 66,8 & 79,7 & 108,9 & 119,8 \\
\hline
\end{tabular}

*) Perkiraan

Sumber: Bahan paparan Direktur Jenderal Mineral dan Batubara Dalam Rapat Kerja Tahun 2012 Dengan Kementerian Perindustrian, Hotel Grand Sahid Jakarta, 1 Februari 2012.

Tabel 2. Produksi Mineral (P), Ekspor (E) dan Pengolahan Domestik (D)

\begin{tabular}{|c|c|c|c|c|c|c|c|c|c|c|c|c|c|c|}
\hline \multirow{2}{*}{ No } & \multirow{2}{*}{ Komoditas } & \multirow[t]{2}{*}{ Unit } & \multicolumn{3}{|c|}{2009} & \multicolumn{3}{|c|}{2010} & \multicolumn{3}{|c|}{2011} & \multicolumn{3}{|c|}{2012} \\
\hline & & & $\mathrm{P}$ & $\mathrm{E}$ & $\mathrm{D}$ & $\mathrm{P}$ & $\mathrm{E}$ & $\mathrm{D}$ & $\mathrm{P}$ & $\mathrm{E}$ & $\mathrm{D}$ & $\mathrm{P}$ & $\mathrm{E}$ & $\mathrm{D}$ \\
\hline 1 & Tembaga & $\begin{array}{l}\text { Ribu } \\
\text { ton }\end{array}$ & 999 & 703 & 287 & 878 & 612 & 228 & 482 & 310 & 193 & 674 & 431 & 418 \\
\hline 2 & Emas & Ton & 129 & 104 & 33 & 105 & 81 & 22 & 63 & 51 & 19 & 66 & 53 & 25 \\
\hline 3 & Perak & Ton & 328 & 306 & 83 & 279 & 227 & 63 & 170 & 148 & 51 & 250 & 218 & 85 \\
\hline 4 & $\begin{array}{l}\mathrm{Ni}+\mathrm{Co} \text { in } \\
\text { Matte }\end{array}$ & $\begin{array}{l}\text { Ribu } \\
\text { ton }\end{array}$ & 68 & 61 & 0 & 77 & 77 & 0 & 72 & 68 & 0 & 71 & 72 & 0 \\
\hline 5 & Timah & $\begin{array}{l}\text { Ribu } \\
\text { ton }\end{array}$ & 60 & 65 & 0 & 48 & 47 & 0 & 54 & 52 & 0 & 72 & 72 & 0 \\
\hline 6 & Bijih Nikel & $\begin{array}{l}\text { Juta } \\
\text { ton }\end{array}$ & 6,1 & 5 & 0 & 7,5 & 6,4 & 0 & 32,9 & 32,6 & 0 & 34 & 34 & 0 \\
\hline 7 & Ferronikel & $\begin{array}{l}\text { Ribu } \\
\text { ton }\end{array}$ & 13 & 14 & 0 & 19 & 18 & 0 & 18 & 18 & 0 & 19 & 19 & 0 \\
\hline 8 & Bauksit & $\begin{array}{l}\text { Juta } \\
\text { ton }\end{array}$ & 5,4 & 4,7 & 0,2 & 15,6 & 15,2 & 0 & 40,7 & 39,7 & 0,03 & 10 & 10 & 0 \\
\hline 9 & Bijih Besi & $\begin{array}{l}\text { Juta } \\
\text { ton } \\
\end{array}$ & 5,2 & 5,1 & 0 & 3,9 & 3,9 & 0 & 13,1 & 12,8 & 0 & 5 & 5 & 0 \\
\hline
\end{tabular}

Sumber: Bahan paparan Direktur Jenderal Mineral dan Batubara Dalam Rapat Kerja Tahun 2012 Dengan Kementerian Perindustrian, Hotel Grand Sahid Jakarta, 1 Februari 2012.

pengolahan dan pemurnian hasil penambangan di dalam negeri. Selanjutnya, UU tersebut menjelaskan bahwa diwajibkannya kegiatan tersebut ditujukan, antara lain, untuk meningkatkan dan mengoptimalkan nilai tambang dari produk, tersedianya bahan baku industri, penyerapan tenaga kerja, dan peningkatan penerimaan negara.

Indonesia merupakan salah satu penghasil bahan tambang mineral terbesar di dunia, meskipun secara potensi tidak besar (Djamaluddin, dkk., 2012:1). Namun, produksi mineral Indonesia lebih banyak diekspor daripada diserap oleh pasar domestik. Hal ini terlihat dari data produksi, ekspor, dan pengolahan domestik seperti pada Tabel 2 .

Berkenaan dengan perdagangan mineral, Menteri Keuangan menerbitkan Peraturan Menteri Keuangan Nomor 75/PMK.011/2012 tentang Penetapan Barang Ekspor yang Dikenakan Bea Keluar dan Tarif Bea Keluar serta Peraturan Menteri Keuangan Nomor 6/PMK.011/2014 tentang Perubahan Kedua Atas Peraturan Menteri Keuangan Nomor 75/PMK.011/2012 tentang Penetapan Barang Ekspor yang Dikenakan Bea Keluar dan Tarif Bea Keluar. Pengenaan Bea Keluar (BK) terhadap produk mineral sebagaimana diatur dalam PMK tersebut dimaksudkan untuk menghambat ekspor mineral sehingga diperoleh ketersediaan bahan baku industri pengolahan dan pemurnian mineral di dalam negeri.
Kebijakan pengenaan BK didasarkan pada UU 10/1995 tentang Kepabeanan sebagaimana diubah dengan UU 17/2006. Selanjutnya, pengaturan lebih lanjut terhadap pengenaan BK diatur di dalam PP 55/2008 tentang Pengenaan Bea Keluar Terhadap Barang Ekspor. PP 55/2008 menyebutkan bahwa pengenaan BK dilakukan oleh menteri keuangan. Berkenaan dengan hal tersebut, menteri keuangan telah menerbitkan PMK 75/2012 tentang Penetapan Barang Ekspor yang Dikenakan Bea Keluar dan Tarif Bea Keluar. Selanjutnya, melalui PMK 6/2014, menteri keuangan menetapkan kenaikan tarif BK mineral sehingga memunculkan dilema dalam kebijakan pengelolaan mineral. Di satu sisi, ekspor mineral mentah telah berperan menggerakkan aktivitas ekonomi masyarakat. Di sisi lain, pengenaan BK yang tinggi dapat menghambat ekspor produk mineral. Situasi ini tampak semakin sulit karena perusahaan pertambangan belum siap melakukan kegiatan pengolahan dan pemurnian hasil penambangan di dalam negeri. Kenaikan tarif BK sepintas dapat menguntungkan penerimaan negara, tetapi berpotensi melemahkan perdagangan/ekspor mineral. Akibatnya, masyarakat dirugikan terhadap kebijakan tersebut. Oleh karena itu, penetapan BK mineral kiranya perlu mempertimbangkan keselarasan dengan UU 4/2009 dan dinamika yang terjadi di masyarakat. 
Berkenaan dengan pengenaan BK Mineral, penulis tertarik melakukan kajian terhadap penetapan BK Mineral di dalam PMK 6/2014 dengan tujuan kebijakan pengelolaan mineral di dalam UU 4/2009. Kesesuaian tersebut akan memberikan keyakinan arah kebijakan fiskal dalam mendukung pengelolaan kekayaan alam bagi sebesar-besar kemakmuran rakyat.

Berdasarkan latar belakang yang telah dijelaskan, penelitian ini bertujuan mengetahui (1) Urgensi penetapan BK mineral dalam mendukung tujuan UU 4/2009, dan (2) dampak penetapan BK mineral dalam PMK 6/2014 terhadap masyarakat, investor pertambangan dan pemerintah.

\section{METODE PENELITIAN}

Penelitian ini menggunakan metode penelitian kualitatif deskriptif dengan berusaha memberikan gambaran dan penjelasan secara tertulis terhadap sejumlah data yang telah dikumpulkan. Proses analisis dilakukan menggunakan norma-norma hukum, teori ekonomi dan keuangan publik. Penelitian ini menggunakan studi literatur. Jenis data yang diperoleh adalah data sekunder yang dikumpulkan melalui penelitian kepustakaan.

Kajian ini diawali dengan kegiatan pra penelitian, meliputi: Perumusan masalah, pengumpulan dan pemilihan bahan kepustakaan serta studi awal terhadap bahan kepustakaan tersebut. Tahap pelaksanaan dilakukan melalui penelitian kepustakaan yaitu dengan membaca, mengkaji dan membandingkan berbagai peraturan perundangundangan, buku, artikel, surat kabar/majalah dan/atau sumber bacaan lain yang diambil melalui media elektronik (internet) yang berhubungan dengan topik kajian. Selanjutnya, tahap penyelesaian dilaksanakan dengan cara menganalisis dan menyusun data hasil penelitian secara sistematis mengikuti alur sistematika pembahasan.

\section{HASIL DAN PEMBAHASAN}

\section{Penetapan Bea Keluar dan Pengelolaan Sumber Daya Mineral}

Peran Pemerintah sangat diperlukan dalam perekonomian dan berfungsi dalam mempercepat pertumbuhan ekonomi untuk meningkatkan standar kehidupan penduduk pada tingkat yang layak. Fungsi Pemerintah dalam perekonomian dapat dikelompokkan ke dalam 3 fungsi, yaitu: fungsi alokasi, fungsi distribusi, dan fungsi stabilisasi (Fuad, dkk., 2004:24).

Secara umum, APBN mempunyai peran strategis untuk melaksanakan tiga fungsi ekonomi Pemerintah. Fungsi alokasi berkaitan dengan alokasi anggaran Pemerintah untuk tujuan pembangunan nasional, terutama dalam melayani kebutuhan masyarakat dan mendukung penciptaan akselerasi pertumbuhan ekonomi yang tinggi dan berkualitas.
Fungsi distribusi berkaitan dengan distribusi pendapatan dan subsidi dalam upaya peningkatan kesejahteraan rakyat, sedangkan fungsi stabilisasi berkaitan dengan upaya untuk menjaga stabilitas dan akselerasi kinerja ekonomi sehingga perekonomian tetap pada kondisi yang produktif, efisien, dan stabil (Republik Indonesia, 2014:1-2).

Kebijakan fiskal pemerintah tercermin dalam Anggaran Pendapatan dan Belanja Negara yang mencakup kebijakan dari sisi penerimaan dan belanja negara. Berkenaan dengan fungsi stabilisasi, kebijakan fiskal mempengaruhi secara langsung tingkat permintaan barang dan jasa (Fuad, dkk., 2004:52).

Pajak berfungsi sebagai sumber penerimaan negara (fungsi budget), yaitu mengumpulkan dana yang akan digunakan bagi pembiayaan kegiatan rutin operasional pemerintah mengatur negara. Selain berfungsi budget, pajak berfungsi sebagai alat pengaturan serta pengawasan kegiatan-kegiatan yang dilaksanakan sektor swasta (fungsi regulator). Pada fungsi regulator, kebijakan perpajakan dimaksudkan untuk mencapai tingkat pertumbuhan ekonomi yang diinginkan dengan cara mengatur pola produksi dan konsumsi barang-barang ekonomi. Dengan sistem perpajakan, pemerintah dapat mendorong investasi yang menghasilkan barang-barang produksi tertentu atau sebaliknya (Fuad, dkk., 2004:125).

Kebijakan pajak seharusnya difokuskan pada pertumbuhan ekonomi nasional dengan memberikan insentif pada aktivitas-aktivitas produktif nasional. Ekonomi yang terus tumbuh dan pasar yang efisien harus terus dijaga agar kemakmuran masyarakat tidak rusak akibat adanya penerapan kebijakan perpajakan (Fuad, dkk., 2004:146-147).

Salah satu pungutan negara yang difungsikan sebagai regulator adalah pengenaan pajak ekspor guna mengekang pertumbuhan ekspor komoditi tertentu dalam rangka menghindari kelangkaan produk tersebut di dalam negeri (Fuad, dkk., 2004:268). Pengertian pajak ekspor tersebut memiliki kesamaan dengan BK dalam Pasal 1 UU 17/2006 yaitu pungutan negara berdasarkan undangundang yang dikenakan terhadap barang ekspor. Pasal 2 ayat 2 PP 55/2008 menyatakan bahwa BK bertujuan untuk (1) menjamin terpenuhinya kebutuhan dalam negeri; (2) melindungi kelestarian sumber daya alam; (3) mengantisipasi kenaikan harga yang cukup drastis dari komoditas ekspor tertentu di pasaran internasional; atau (4) menjaga stabilitas harga komoditas tertentu di dalam negeri. BK bukan merupakan pajak dan lebih ke pengertian pungutan negara dengan tujuan untuk melindungi kepentingan nasional dan kepentingan masyarakat (Purwito, 2009:43).

Kebijakan perpajakan terkait fungsi regulator diterapkan Pemerintah dalam APBN 2014. Pemerintah melakukan penyempurnaan kebijakan insentif perpajakan untuk mendukung iklim usaha dan investasi, antara lain melalui penyusunan 
kebijakan fiskal untuk mendukung penghiliran pertambangan melalui kebijakan disinsentif fiskal BK untuk ekspor barang tambang mentah, dan insentif fiskal untuk penanaman modal bagi industri hilir pertambangan (Republik Indonesia, 2014:3.28).

Berkenaan dengan kebijakan pengelolaan sumber daya mineral, Pasal 33 ayat 3 UUD 1945 menyatakan bahwa bumi dan air dan kekayaan alam yang terkandung di dalamnya dikuasai oleh negara dan dipergunakan untuk sebesar-besar kemakmuran rakyat. Makna penguasaan negara mencakup, antara lain: kekuasaan untuk mengatur (regelendaad), dan mengawasi (toezichthoudensdaad) cabang-cabang produksi yang penting bagi negara dan/atau menguasai hajat hidup orang banyak (Mahkamah Konstitusi, 2008).

Fungsi pengaturan oleh negara dilakukan melalui kewenangan legislasi oleh DPR bersama Pemerintah, dan regulasi oleh Pemerintah. Adapun fungsi pengawasan oleh negara dilakukan oleh Negara, c.q. Pemerintah, dalam rangka mengawasi dan mengendalikan agar pelaksanaan penguasaan oleh negara atas sumber-sumber kekayaan dimaksud benar-benar dilakukan untuk sebesar-besarnya kemakmuran seluruh rakyat (Mahkamah Konstitusi, 2003).

Pasal 33 ayat (3) UUD 1945 mengamanatkan bahwa penguasaan negara sumber daya alam dilaksanakan demi mewujudkan kemakmuran rakyat. Kemakmuran merupakan kata benda yang bermakna keadaan makmur. Kata makmur merupakan kata sifat yang berarti serba kecukupan dan tidak kekurangan (Pusat Bahasa Kementerian Pendidikan Nasional, diakses 26 Mei 2014). Dengan demikian, dapat dipahami bahwa penguasaan negara atas seluruh kekayaan alam ditujukan untuk mencukupi kebutuhan dan meningkatkan taraf kehidupan masyarakat secara merata.

Makna mewujudkan sebesar-besar kemakmuran rakyat dalam Pasal 33 ayat 3 UUD 1945 tercermin dalam UU 4/2009. Pasal 3 UU 4/2009 menyebutkan tujuan pengelolaan mineral dan batubara adalah: (a) menjamin efektivitas pelaksanaan dan pengendalian kegiatan usaha pertambangan secara berdaya guna, berhasil guna, dan berdaya saing; (b) menjamin manfaat pertambangan mineral dan batubara secara berkelanjutan dan berwawasan lingkungan hidup; (c) menjamin tersedianya mineral dan batubara sebagai bahan baku dan/atau sebagai sumber energi untuk kebutuhan dalam negeri; (d) mendukung dan menumbuhkembangkan kemampuan nasional agar lebih mampu bersaing di tingkat nasional, regional, dan internasional; (e) meningkatkan pendapatan masyarakat lokal, daerah, dan negara, serta menciptakan lapangan kerja untuk sebesar-besar kesejahteraan rakyat; dan (f) menjamin kepastian hukum dalam penyelenggaraan kegiatan usaha pertambangan mineral dan batubara.

UU 4/2009 telah memberikan arah pengelolaan sumber daya mineral. UU tersebut menegaskan bahwa pengelolaan sumber daya mineral harus dikuasai oleh Negara untuk memberi nilai tambah secara nyata bagi perekonomian nasional dalam usaha mencapai kemakmuran dan kesejahteraan rakyat secara berkeadilan. Pengertian nilai tambah yang umum dikenal di kalangan yang menggunakan parameter ekonomi sebagai acuan adalah perbedaan antara nilai output dan nilai input atau peningkatan harga material yang dihasilkan dari proses pengolahan mineral dan logam persatuan berat logam/mineral. Pengertian nilai tambah juga dapat dikaitkan dengan kepentingan lain yang lebih luas termasuk setiap manfaat ekonomi, sosial dan peradaban yang dihasilkan, seperti peningkatan pertumbuhan ekonomi, lapangan kerja baru, multiplier effect sektor lain, penguasaan ilmu pengetahuan \& teknologi, kemudahan dan kecepatan proses, dan peningkatan ketahanan nasional (Djamaluddin, dkk., 2012:5). Adapun maksud peningkatan nilai tambah dalam kegiatan pengolahan dan pemurnian, sebagaimana disebutkan dalam penjelasan pasal 103 ayat 1 UU 4/2009, untuk meningkatkan dan mengoptimalkan nilai tambang dari produk, tersedianya bahan baku industri, penyerapan tenaga kerja, dan peningkatan penerimaan negara.

UU 4/2009 memberikan arah pengelolaan potensi mineral secara mandiri, andal, transparan, berdaya saing, efisien dan berwawasan lingkungan, guna menjamin pembangunan nasional secara berkelanjutan. UU 4/2009 mengamanatkan pembangunan industri pengolahan berbasis mineral agar sumber daya mineral dapat memberikan manfaat optimal bagi kepentingan nasional.

Sebagai gambaran, kebijakan peningkatan nilai tambah tercermin pada komoditas mineral tembaga, nikel dan bauksit. Berdasarkan kajian Kementerian ESDM dengan menggunakan data tahun 2011, terdapat potensi peningkatan nilai tambah dari bijih dan konsentrat tembaga sebesar USD 13.198.637.400 dan perkiraan penyerapan tenaga kerja sebanyak 32.600 orang. Adapun potensi peningkatan nilai tambah dari bijih dan konsentrat nikel sebesar USD 241.489.616.800 dan penyerapan tenaga kerja sebanyak 1.700 .000 orang. Sementara itu, potensi nilai tambah bauksit diperkirakan sebesar USD 13.412.471.160 dengan tenaga kerja sebanyak 670.000 orang. Kegiatan peningkatan nilai tambah mineral di dalam negeri berpotensi meningkatkan penerimaan negara dari pajak penghasilan, PNBP (royalti dan landrent), retribusi daerah, dan peningkatan aktivitas ekonomi di daerah (Pusat Data dan Informasi Energi dan Sumber Daya Mineral, 2012:70-103).

Guna mendukung tujuan dalam UU 4/2009, Pemerintah menerbitkan Peraturan Pemerintah Nomor 23 Tahun 2010 tentang Pelaksanaan Kegiatan Usaha Pertambangan Mineral dan Batubara sebagaimana telah diubah terakhir dengan PP 1/2014 
Tabel 3. Perkembangan Ekspor Beberapa Komoditas Hasil Pertambangan Tahun 2010 - 2013

\begin{tabular}{clcccc}
\hline \multirow{2}{*}{ No } & \multirow{2}{*}{ Komoditas } & \multicolumn{4}{c}{ Berat Bersih (Ton) } \\
\cline { 3 - 6 } & & 2010 & 2011 & 2012 & 2013 \\
\hline 1 & Bijih Tembaga & 2.642 .087 & 1.471 .601 & 1.124 .444 & 1.453 .956 \\
2 & Bijih Nikel & 17.566 .047 & 40.792 .165 & 48.449 .392 & 64.802 .857 \\
3 & Bauksit & 27.410 .375 & 40.644 .118 & 29.521 .625 & 57.104 .931 \\
4 & Bijih Timah/Tin & 0 & 1 & 533 & 176 \\
\hline
\end{tabular}

Sumber: Badan Pusat Statistik, Desember 2011 dan 2013.

Tabel 4. Ekspor Mineral 2012-2013

\begin{tabular}{clcc}
\hline \multirow{2}{*}{ No } & \multicolumn{1}{c}{ Uraian Barang } & \multicolumn{2}{c}{ Berat $(\mathrm{Kg})$} \\
\cline { 3 - 4 } & & 10.432 .544 .627 & 2013 \\
\hline 1 & Biji dan Konsentrat Besi (non aglomerasi) & 1.113 .207 .171 & 48.600 .920 \\
2 & Biji dan Konsentrat Besi (aglomerasi) & 19.081 .118 & 3.945 .221 \\
3 & Biji dan konsentrat Mangan & 1.123 .541 .044 & 1.453 .731 .863 \\
4 & Biji dan konsentrat tembaga & 5.083 .897 & 10.325 .040 \\
5 & Biji dan konsentrat timbal & 1.334 .982 & 2.442 .590 \\
6 & Biji dan konsentrat seng & 6.258 .500 & 6.482 .000 \\
7 & Biji dan konsentrat titanium dan ilmenit & &
\end{tabular}

Sumber: Badan Pusat Statistik

tentang Perubahan Kedua Atas Peraturan Pemerintah Nomor 23 Tahun 2010 tentang Pelaksanaan Kegiatan Usaha Pertambangan Mineral dan Batubara. PP tersebut mengatur kewajiban kegiatan pengolahan dan pemurnian mineral logam di dalam negeri bagi seluruh perusahaan pertambangan. Perusahaan pertambangan dimungkinkan menjual produk mineral logam ke luar negeri (ekspor) setelah memenuhi batasan minimum pengolahan dan pemurnian dengan kriteria tertentu.

Berkenaan dengan kebijakan pengelolaan mineral, Pemerintah menerbitkan PMK 75/2012. PMK tersebut mengenakan tarif BK sebesar $20 \%$ terhadap 21 jenis mineral logam mentah (belum diolah), diantaranya bijih tembaga, nikel, bauksit, dan timah. Namun pengenaan tarif tersebut belum efektif menghambat ekspor mineral. Kecuali bijih tembaga yang telah diolah menjadi konsentrat, ekspor bijih mineral tercatat mengalami peningkatan dari tahun ke tahun. Setelah diberlakukannya PMK 75/2012 pada tanggal 12 Mei 2012, ekspor mineral sempat menurun tetapi pada tahun 2013 tercatat mengalami peningkatan, bahkan lebih besar daripada sebelum dikenakan BK. Data volume ekspor bijih mineral logam seperti pada Tabel 3.

Berdasarkan data ekspor pada tabel di atas, penetapan tarif BK dalam PMK 75/2012 disikapi berbeda oleh perusahaan pertambangan. Sebagian perusahaan (timah) mengurangi volume ekspor, tetapi sejumlah perusahaan lain justru meningkatkan volume ekspornya. Pengenaan BK berpotensi mengurangi profit margin perusahaan pertambangan sehingga untuk mendapatkan akumulasi keuntungan yang diinginkan, perusahaan semakin meningkatkan volume ekspornya demi mengkompensasi penurunan laba perusahaan.
Dibandingkan tahun 2012, volume ekspor biji dan konsentrat mineral tahun 2013 mengalami kenaikan. Apabila dihubungkan dengan kemampuan domestik dalam mengolah mineral mentah menjadi konsentrat, maka diperkirakan lonjakan volume ekspor tersebut terjadi sebagai akibat dari kegiatan penambangan secara masif. Hal ini menimbulkan kekhawatiran terhadap ketersediaan bahan baku mineral pada masa yang akan datang, mengingat mineral termasuk sumber daya alam yang tidak dapat diperbarui. Selain itu, eksploitasi sumber daya alam yang berlebihan juga mengancam kelestarian lingkungan.

Peraturan Menteri Energi dan Sumber Daya Mineral Nomor 1 Tahun 2014 tentang Peningkatan Nilai Tambah Mineral Melalui Kegiatan Pengolahan dan Pemurnian Mineral di Dalam Negeri menetapkan batasan minimum komoditas mineral yang dapat dijual ke luar negeri. Pemerintah melarang seluruh ekspor mineral mentah sekaligus menegaskan kewajiban pengolahan dan pemurnian mineral di dalam negeri. Pada dasarnya, seluruh komoditas mineral harus melalui proses pengolahan dan pemurnian di dalam negeri. Namun, terdapat sejumlah komoditas tertentu yang boleh diekspor setelah melalui kegiatan pengolahan dan memenuhi batasan minimum tertentu. Penjualan produk mineral hasil pengolahan tersebut diperkenankan sampai dengan tahun 2016.

Guna memperkuat kebijakan pengelolaan sumber daya mineral, Pemerintah menerbitkan PMK 6/2014. Melalui PMK tersebut, Pemerintah berupaya mendorong percepatan pembangunan pabrik pengolahan dan pemurnian mineral. Konsideran Menimbang PMK tersebut menyatakan bahwa pengenaan $\mathrm{BK}$ bertujuan menjamin ketersediaan 
Tabel 5. Barang Ekspor Berupa Produk Mineral yang Dikenakan Bea Keluar dan Tarif Bea Keluar

\begin{tabular}{|c|c|c|c|c|c|c|c|}
\hline \multirow[b]{3}{*}{ No } & \multirow[b]{3}{*}{ Uraian } & \multicolumn{6}{|c|}{ Tarif Bea Keluar (\%) } \\
\hline & & \multicolumn{2}{|c|}{2014} & \multicolumn{2}{|c|}{2015} & \multicolumn{2}{|c|}{2016} \\
\hline & & $\begin{array}{c}\text { Sejak } 12 \\
\text { Januari sd } \\
\text { 30 Juni }\end{array}$ & $\begin{array}{l}\text { Sejak 1 Juli } \\
\text { sd } 31 \\
\text { Desember }\end{array}$ & $\begin{array}{c}\text { Sejak 1 } \\
\text { Januari sd } \\
\text { 30 Juni }\end{array}$ & $\begin{array}{l}\text { Sejak 1 Juli } \\
\text { sd } 31 \\
\text { Desember }\end{array}$ & $\begin{array}{c}\text { Sejak 1 } \\
\text { Januari sd } \\
\text { 30 Juni }\end{array}$ & $\begin{array}{l}\text { Sejak 1 Juli } \\
\text { sd } 31 \\
\text { Desember }\end{array}$ \\
\hline 1 & $\begin{array}{l}\text { Konsentrat tembaga } \\
\text { dengan kadar } \geq 15 \% \\
\mathrm{Cu}\end{array}$ & $25 \%$ & $25 \%$ & $35 \%$ & $40 \%$ & $50 \%$ & $60 \%$ \\
\hline 2 & $\begin{array}{l}\text { Konsentrat besi } \\
\text { (hematit, magnetit, } \\
\text { pirit) dengan kadar } \geq \\
62 \% \mathrm{Fe}\end{array}$ & $20 \%$ & $20 \%$ & $30 \%$ & $40 \%$ & $50 \%$ & $60 \%$ \\
\hline & $\begin{array}{l}\text { Konsentrat besi } \\
\text { (Gutit/laterit) dengan } \\
\text { kadar } \geq 51 \% \text { Fe dan } \\
\text { kadar }(\mathrm{Al} 2 \mathrm{O} 3+\mathrm{SiO} 2) \geq \\
10 \%\end{array}$ & $20 \%$ & $20 \%$ & $30 \%$ & $40 \%$ & $50 \%$ & $60 \%$ \\
\hline 3 & $\begin{array}{l}\text { Konsentrat mangan } \\
\text { dengan kadar } \geq 49 \% \\
\text { Mn }\end{array}$ & $20 \%$ & $20 \%$ & $30 \%$ & $40 \%$ & $50 \%$ & $60 \%$ \\
\hline 4 & $\begin{array}{l}\text { Konsentrat timbal } \\
\text { dengan kadar } \geq 57 \% \\
\mathrm{~Pb}\end{array}$ & $20 \%$ & $20 \%$ & $30 \%$ & $40 \%$ & $50 \%$ & $60 \%$ \\
\hline 5 & $\begin{array}{l}\text { Konsentrat seng } \\
\text { dengan kadar } \geq 52 \% \\
\mathrm{Zn}\end{array}$ & $20 \%$ & $20 \%$ & $30 \%$ & $40 \%$ & $50 \%$ & $60 \%$ \\
\hline 6 & $\begin{array}{l}\text { Konsentrat ilmenite } \\
\text { dengan kadar } \mathrm{Fe} \geq \\
58 \% \text { (bentuk pasir) } \\
\text { dan kadar Fe } \geq 56 \% \\
\text { (bentuk pellet) }\end{array}$ & $20 \%$ & $20 \%$ & $30 \%$ & $40 \%$ & $50 \%$ & $60 \%$ \\
\hline & $\begin{array}{l}\text { Konsentrat titanium } \\
\text { lainnya dengan kadar } \\
\mathrm{Fe} \geq 58 \% \text { (bentuk } \\
\text { pasir) dan kadar } \mathrm{Fe} \geq \\
56 \% \text { (bentuk pellet) }\end{array}$ & $20 \%$ & $20 \%$ & $30 \%$ & $40 \%$ & $50 \%$ & $60 \%$ \\
\hline
\end{tabular}

Sumber: Peraturan Menteri Keuangan 6/2014

bahan baku industri pengolahan dan pemurnian mineral serta menjaga kelestarian sumber daya alam. BK tersebut diberlakukan secara bertahap mulai $20 \%$ dengan kenaikan setiap semester sampai dengan 2016. Adapun produk mineral hasil pengolahan yang bisa diekspor dan tarif BK sebagaimana tercantum di Tabel 5.

PMK 6/2014 memberikan peluang ekspor, meskipun pada periode selanjutnya, perusahaan pertambangan harus semakin menyadari bahwa peluang ekspor produk mineral olahan akan semakin dibatasi. Dengan kata lain, perusahaan pertambangan dimungkinkan tetap berproduksi sekaligus didorong untuk mempercepat penyelesaian pembangunan fasilitas pengolahan dan pemurnian mineral (Asosiasi Pertambangan Indonesia, diakses $30 \mathrm{Mei}$ 2014).

Keberadaan BK Mineral seharusnya dapat memperkuat kemampuan nasional dalam mengelola dan mengusahakan potensi mineral secara mandiri, andal, transparan, berdaya saing, efisien, dan berwawasan lingkungan. Namun merujuk data ekspor tahun 2013 pada tabel 4, kebijakan BK mineral tampak kurang berhasil dalam mengendalikan ekspor mineral mentah. Oleh karena itu, PMK 6/2014 yang menetapkan skema tarif BK yang lebih tinggi dipandang akan lebih efektif dalam mendukung kebijakan pengelolaan sumber daya mineral sesuai UU 4/2009.

Berkenaan dengan isu lingkungan, kegiatan penambangan telah menciptakan nilai kerusakan lingkungan yang besar. Hasil valuasi di Kabupaten Tanah Laut tahun 2004 menunjukkan bahwa nilai kerusakan akibat tambang illegal di kabupaten tersebut mencapai Rp 700 miliar atau 2,3 kali lipat APBD kabupaten tersebut yang hanya Rp 300 miliar pada tahun yang sama. Hal ini menunjukkan bahwa kerusakan lingkungan yang diciptakan oleh pertambangan semakin membuktikan bahwa aktivitas pertambangan yang tidak dikelola dengan baik menimbulkan persoalan besar bagi pembangunan masyarakat (Komisi Pemberantasan 
Korupsi, 2013:53).

Kegiatan usaha pertambangan memberikan dampak negatif terhadap lingkungan fisik, kimia, dan biologi. Kerusakan-kerusakan tersebut diantaranya kerusakan bentang alam, penurunan kesuburan tanah, rusaknya flora dan fauna endemik, meningkatnya polusi udara dan debu, erosi, dan sedimen yang memicu banjir, kebisingan, rusaknya jalanan umum yang digunakan untuk memuat alat-alat berat perusahaan, dan adanya limbah yang dapat masuk ke lahan-lahan pertanian dan sungai sehingga merusak biota perairan dan sumber air yang digunakan untuk air bersih (minum) dan mencuci (Raden, dkk., 2010:71).

PMK 6/2014 mengenakan BK dengan tarif sebesar 20-25\% pada tahun 2014 dan sampai dengan $60 \%$ pada tahun 2016. Meskipun aturan BK ini masih memungkinkan dilakukannya ekspor dalam bentuk pengolahan mineral (konsentrat) sampai dengan tahun 2016, tetapi tarif BK mineral semakin meningkat hingga mencapai batas maksimal $60 \%$.

Pemberlakuan PP 1/2014 dan diikuti dengan PMK 6/2014 menunjukkan efektivitasnya. Hal ini tampak dari data ekspor 2014 yang menunjukkan penurunan ekspor produk mineral. Hal ini terlihat dari data ekspor mineral Januari-April 2014 yang turun dibandingkan dengan periode yang sama pada tahun sebelumnya (www.gatra.com, diakses $22 \mathrm{Mei}$ 2014). Jika pada tahun 2013, nilai ekspor untuk konsentrat mineral mencapai 4,5 miliar dollar AS, maka sampai dengan April 2014 hampir tidak ada ekspor mineral (http://bisniskeuangan.kompas.com, diakses 5 Juni 2014).

Kebijakan hilirisasi mineral di dalam negeri akan meningkatkan nilai pemasaran dan pendapatan dari komoditas mineral yang telah diolah sehingga mampu memberikan keuntungan ekonomi yang lebih besar di dalam negeri. Hal ini mendukung tujuan pemanfaatan potensi mineral bagi perekonomian nasional dalam usaha mencapai kemakmuran dan kesejahteraan rakyat secara berkeadilan. Potensi mineral di dalam negeri juga dapat dimanfaatkan sebesar-besarnya bagi keuntungan rakyat. Selain itu, kebijakan tersebut dapat mengurangi ekspor mineral mentah dan kegiatan pengambilan sumber daya mineral di alam sehingga lebih menjamin kelestarian lingkungan.

Kebijakan BK dalam PMK 6/2014 diharapkan memperkuat kemampuan nasional dalam mengelola dan mengusahakan potensi mineral secara mandiri, andal, transparan, berdaya saing, efisien, dan berwawasan lingkungan. Pengenaan BK produk mineral akan lebih menjamin ketersediaan bahan baku mineral di dalam negeri. Selain itu, ketersediaan bahan baku dapat menarik investasi baru dalam bidang pengolahan mineral sehingga mampu mendorong perekonomian nasional dan pembangunan daerah secara merata. Apabila pabrik pengolahan dan pemurnian mineral belum dibangun, maka kegiatan penambangan mineral di alam akan berkurang atau berhenti sehingga ekosistem lebih terjaga kelestariannya dan kekayaan alam tersebut dapat dinikmati lebih lama. Sementara itu, apabila pabrik pengolahan dan pemurnian dapat dibangun, maka masyarakat akan mendapatkan keuntungan ekonomi yang semakin tinggi.

PMK 6/2014 diharapkan dapat mendorong investor untuk mempercepat pembangunan pabrik pemurnian mineral di dalam negeri. Dengan adanya tarif BK yang tinggi diperkirakan volume ekspor mineral akan semakin turun. Meskipun terjadi penurunan volume ekspor konsentrat, tetapi penurunan volume ini akan dikompensasi dengan peningkatan nilai ekspor dari produk mineral yang telah dimurnikan yang nilainya jauh lebih tinggi hingga beratus-ratus kali lipat. Peningkatan nilai ini akan meningkatkan pendapatan masyarakat dan berdampak positif terhadap perekonomian nasional secara lebih luas. BK mineral ini akan mengurangi aktivitas penambangan serta mengalihkan aktivitas tersebut ke dalam proses pengolahan dan pemurnian. Sehingga diharapkan mengurangi risiko kerusakan lingkungan sebagai akibat dari penambangan secara besar-besaran. Selain itu, diharapkan melalui kegiatan pengolahan dan pemurnian mineral ini, pada nantinya akan membuka lebih banyak peluang bagi tenaga kerja terampil/berkeahlian. Penurunan ekspor ini diikuti dengan penurunan tingkat produksi pertambangan karena pabrik pengolahan dan pemurnian mineral domestik belum dibangun serta terjadi penurunan daya saing komoditas mineral Indonesia sebagai akibat pengenaan $\mathrm{BK}$ mineral yang relatif tinggi.

\section{Dampak Pengenaan Bea Keluar Mineral}

Setiap kegiatan pembangunan di bidang pertambangan pasti menimbulkan dampak positif maupun dampak negatif. Dampak positif dari kegiatan pembangunan di bidang pertambangan antara lain: (1) memberikan nilai tambah secara nyata kepada pertumbuhan ekonomi nasional; (2) meningkatkan Penerimaan Asli Daerah (PAD); (3) menampung tenaga kerja, terutama masyarakat lingkar tambang; (4) meningkatkan ekonomi masyarakat lingkar tambang. Dampak negatif dari pembangunan di bidang pertambangan diantaranya: (1) kehancuran lingkungan hidup; (2) penderitaan masyarakat adat; (3) menurunnya kualitas hidup penduduk lokal (Dewi, 2010:34-35).

Pengaruh pajak terhadap penggunaan faktorfaktor produksi dipengaruhi elastisitas permintaan terhadap barang-barang yang dihasilkan. Barangbarang yang tingkat permintaannya in-elastis sempurna tidak akan terpengaruh dengan adanya pengenaan pajak. Konsumen akan membayar seluruh beban pajak yang ditambahkan pada harga barang. Sebaliknya, jika elastisitas permintaan barang adalah sempurna, perusahaan tidak dapat mengalihkan beban pajaknya pada harga barang (Fuad, dkk., 2004:143). 
Tabel 6. Perbandingan Ekspor Komoditas Hasil Pertambangan Januari 2013 dan Januari 2014

\begin{tabular}{|c|c|c|c|c|c|c|}
\hline \multirow{2}{*}{ Jenis Barang } & \multicolumn{2}{|c|}{ Berat Bersih (Ton) } & \multirow{2}{*}{$\begin{array}{c}\text { Perub } \\
(\%)\end{array}$} & \multicolumn{2}{|c|}{ Nilai FOB (Ribu US \$) } & \multirow{2}{*}{$\begin{array}{c}\text { Perub } \\
(\%)\end{array}$} \\
\hline & 2013 & 2014 & & 2013 & 2014 & \\
\hline Biji Tembaga & 93.580 & 56.870 & $-39,23$ & 206.295 & 137.392 & $-33,40$ \\
\hline Biji Nikel & 5.161 .609 & 4.160 .121 & $-19,40$ & 152.204 & 85.913 & $-43,55$ \\
\hline Bauksit & 2.777 .773 & 2.085 .671 & $-24,92$ & 58.171 & 46.492 & $-20,08$ \\
\hline Hasil Tambang Lain & 2.448 .186 & 1.594 .675 & $-34,86$ & 43.895 & 42.907 & $-2,25$ \\
\hline
\end{tabular}

Sumber: Badan Pusat Statistik, Januari 2014.

Penelitian Hidayat Amir mengungkapkan bahwa pembatasan ekspor mineral mentah dalam jangka pendek akan berdampak negatif terhadap perekonomian, khususnya menyebabkan penurunan ekspor mineral mentah dan investasi baru di sektor pertambangan mineral. Namun, kebijakan pembatasan ekspor tersebut akan berdampak positif terhadap perekonomian jika didukung adanya investasi baru di sektor pengolahan mineral sehingga Indonesia dapat mengekspor komoditas mineral olahan (Amir, 2013:19).

Dampak pengenaan BK Mineral mengakibatkan ekspor mineral berkurang. Hal ini terlihat dari data ekspor mineral selama periode bulan Januari-April 2014. Pengenaan BK mineral sebagaimana diatur dalam PMK 6/2014 telah menekan volume ekspor mineral. Berdasarkan data Kemendag, total nilai ekspor mineral dari JanuariMaret 2014 kurang lebih US\$ 500 juta, dengan total volume 994 ribu ton (www.gatra.com, diakses 5 Juni 2014). Angka tersebut menurun dibandingkan periode yang sama pada tahun 2013 sebesar 0,38\% (http://ekonomi.metrotvnews.com, diakses 17 Juni 2014).

Berdasarkan data tabel 6 , volume ekspor mineral turun. Hal ini menunjukkan bahwa tarif BK menyebabkan harga produk mineral mentah Indonesia menjadi mahal atau di atas margin produksi. Adapun rata-rata margin keuntungan perusahaan tambang hanya sekitar $10 \%$, sehingga jika dikenakan BK 20\%$60 \%$ sangat memberatkan (http://nasional.kontan. co.id, diakses 3 Juni 2014). Hal ini menunjukkan bahwa permintaan produk mineral bersifat elastis sehingga pengenaan BK secara tidak langsung akan dibebankan kepada perusahaan pertambangan.

Tujuan pengenaan BK mineral adalah mendukung ketersediaan bahan baku mineral bagi industri pengolahan dan pemurnian di dalam negeri sekaligus menjaga kelestarian lingkungan. Mengingat kapasitas pengolahan dan pemurnian mineral di dalam negeri lebih kecil daripada kapasitas produksi, pengenaan BK dapat mengurangi eksploitasi sumber daya mineral. Penerapan BK pada produk konsentrat Tembaga, Bijih Besi, Pasir Besi, Ilmenite, Mangan, Timbal, dan Seng ini tampak dari volume ekspor mineral yang turun/lebih kecil daripada periode yang sama pada tahun-tahun sebelumnya (http://bisnis.news.viva.co.id, diakses tanggal 28 Mei 2014).
Adapun pertimbangan pemerintah memberikan kelonggaran ekspor sejumlah produk konsentrat mineral antara lain: (1) Konsentrat mangan. Pemerintah mengizinkan ekspor konsentrat mangan dengan pertimbangan bahwa biaya transportasi pengangkutan mangan dari areal pertambangan di Nusa Tenggara ke pabrik pemurnian di Pulau Jawa sangat besar (http://industri.kontan.co.id, diakses 9 Juni 2014). (2) Studi yang dilakukan Lembaga Afiliasi Penelitian dan Industri Institut Teknologi Bandung menemukan jenis mineral yang ekonomis untuk dimurnikan adalah bauksit, nikel, dan bijih besi. Tiga komoditas itu jika diolah akan meningkatkan nilai tambah $70 \%$ terhadap price base. Sementara, tembaga dan zinc (seng) tidak ekonomis untuk dimurnikan di dalam negeri. Konsentrat tembaga telah mencapai $95 \%$ dari price base. Jika dimurnikan, nilai tambahnya hanya 5\%, tetapi dengan nilai investasi hampir setengah dari investasi untuk pengolahan ore menjadi konsentrat. Pengolahan ore menjadi konsentrat tembaga sekitar USS 20 ribu per ton, tetapi pemurnian tembaga (nilai tambah 5\%) membutuhkan investasi US\$ 10 ribu per ton (Asosiasi Pertambangan Indonesia, diakses 5 Maret 2014).

Turunnya nilai ekspor mineral yang tidak diimbangi dengan penyerapan/kemampuan industri pengolahan di dalam negeri mengakibatkan penurunan tingkat produksi/pendapatan perusahaan, pendapatan pekerja, dan aktivitas ekonomi masyarakat sekitar serta penerimaan negara dari pajak dan PNBP. Adapun dampak penurunan aktivitas pertambangan ini dapat diuraikan sebagai berikut:

1. Dampak Bea Keluar Mineral terhadap Ekonomi Masyarakat

Analisis dampak terhadap perekonomian difokuskan pada penyerapan tenaga kerja dan distribusi pendapatan masyarakat. Penyerapan tenaga kerja berperan dalam mengentaskan kemiskinan, pemerataan pendapatan, dan pertumbuhan ekonomi.

Analisis ketenagakerjaan menunjukkan bahwa setiap tenaga kerja akan menafkahi 4 orang bahkan mampu menanggung biaya hidup hingga 10 orang anggota keluarganya. Memperhatikan hal ini, maka penyerapan tenaga kerja dan tingkat pendapatan yang diperoleh tenaga kerja akan menimbulkan manfaat yang sangat besar bagi peningkatan kesejahteraan masyarakat (Badan Pusat Statistik. 
Tabel 7. Pendidikan dan Kewarganegaraan Pekerja pada

Perusahaan Pertambangan Non Migas Tahun 2010-2012

\begin{tabular}{clccc}
\hline No & \multicolumn{1}{c}{ Uraian } & 2010 & 2011 & 2012 \\
\hline 1 & Pasca Sarjana & 426 & 631 & 869 \\
2 & S1/D/IV/DIII & 8.492 & 17.465 & 20.027 \\
3 & Sampai dengan SLTA & 44.916 & 76.274 & 100.456 \\
\hline & Jumlah & 54.106 & 94.792 & 121.856 \\
\hline WNI & 53.834 & 94.370 & 121.352 \\
\hline & WNA & 272 & 422 & 503 \\
\hline
\end{tabular}

Sumber: Badan Pusat Statistik.

2013:18).

Perusahaan pertambangan non minyak dan gas bumi dapat dikatakan padat modal (capital intensive), karena jumlah tenaga kerjanya relatif sedikit dibandingkan dengan sektor lain (seperti industri dan pertanian) yang tenaga kerjanya mencapai jutaan orang. Adapun penyerapan tenaga kerja di subsektor pertambangan mineral pada tahun 2010 berjumlah 54.106 orang yang terdiri dari pendidikan pasca sarjana 426 orang, sarjana dan diploma 8.492 orang dan sampai dengan sekolah lanjutan tingkat atas sebanyak 44.916 orang. Pada tahun 2012, jumlah tenaga kerja mengalami kenaikan. Data tenaga kerja yang bekerja pada Perusahaan Pertambangan Non Migas Tahun 20102012 sebagaimana tercantum dalam tabel 7 (Badan Pusat Statistik. 2013:18-19).

Berkenaan dengan dengan pelarangan ekspor mineral mentah, saat ini sudah ada beberapa perusahaan yang melakukan rasionalisasi pekerja dan kebanyakan dari sektor tambang nikel, bauksit, pasir besi dan bijih besi. Data Asosiasi Pengusaha Bauksit dan Pasir Besi Indonesia (APB3I) menyebutkan sebanyak 40.000 tenaga kerja yang dirumahkan. Jumlah ini berasal dari 51 perusahaan yang menjadi anggota asosiasi. Salah satu anggota asosiasi, PT Central Omega Resources pemilik konsesi tambang nikel di Morowali dan Konawe Utara, telah menghentikan kegiatan penambangan dan merumahkan kurang lebih 3000 orang karyawannya (www.majalahequipment.com, diakses 28 Mei 2014).

Direktorat Jenderal Mineral dan Batubara memperkirakan terjadi rasionalisasi pekerja sebanyak 33.400 orang. Jumlah ini kemudian dirinci dari beberapa komoditas yakni Bauksit sebanyak 12.400 orang, nikel sebanyak 14.000 orang, pasir/bijih besi sebanyak 5.000 orang serta mangan sebanyak 2.000 orang. (www.majalahequipment.com, diakses 28 Mei 2014). Sebagian besar pekerja yang diberhentikan adalah pekerja dari penduduk sekitar dengan posisi sebagai operator tambang hingga geologis. Sementara, pekerja eksplorasi tetap dipertahankan karena kegiatan eksplorasi masih tetap dilakukan. Hal ini berdampak pada perekonomian masyarakat lokal yang bergantung pada industri tambang. Sekitar 70 persen dari karyawan tambang ini adalah masyarakat lokal di sekitar lokasi pertambangan (Asosiasi Pengusaha Mineral Indonesia, diakses 13 Juni 2014).

Selain faktor adanya penyerapan tenaga kerja lokal yang bekerja di perusahaan, peningkatan penghasilan per bulan yang diterima oleh masyarakat disebabkan pula oleh adanya peluang usaha bagi masyarakat yang berada di sekitar aktivitas pertambangan. Peluang usaha yang dapat dikembangkan masyarakat akibat adanya kegiatan pertambangan antara lain: warung makan, warung sembako, rumah sewaan, jasa katering perusahaan, jasa pencucian pakaian/laundry, usaha isi air ulang. Berdasarkan hal tersebut, kegiatan pertambangan dianggap dapat meningkatkan kondisi ekonomi masyarakat sekitar lokasi tambang daripada sebelum adanya aktivitas tersebut (Raden, dkk., 2010:37).

Kasubdit Perdagangan dan Produksi Mineral Kementerian Energi dan Sumber Daya Mineral mengatakan pelarangan ekspor bijih relatif tidak berdampak untuk komodit emas, perak, Ilmenite, tembaga, timbal dan seng. Namun, pelarangan ekspor bijih bauksit, bijih nikel, bijih besi, pasir besi,dan bijih mangan dapat menimbulkan dampak ekonomi, sosial, tenaga kerja, dan keamanan di sekitar wilayah IUP Operasi Produksi mineral. Dampak ini diperkirakan hanya terjadi sementara selama masa transisi selama 2 sampai 3 tahun ke depan, dan seiring dengan selesainya pembangunan akan ada penyerapan tenaga kerja (www.majalahequipment.com, diakses 28 Mei 2014).

\section{Dampak Bea Keluar Mineral terhadap}

Perusahaan Pertambangan

Perusahaan BUMN, PT Aneka Tambang (Persero) Tbk, mencatatkan rugi pada kuartal I 2014 sebesar Rp 272,6 miliar dibandingkan kuartal I 2013 yang membukukan laba Rp 407,6 miliar. Kerugian itu karena perseroan terkena dampak larangan ekspor mineral mentah yang mulai diberlakukan awal tahun ini dan masih rendahnya harga komoditas. Antam membukukan penjualan sebesar Rp 2,3 triliun pada kuartal I 2014 atau turun 31,03 persen dibandingkan periode yang sama tahun lalu sebesar Rp 3,34 triliun. Penurunan penjualan terutama untuk bijih nikel yang anjlok 92,2 persen; emas turun 25,6 persen; dan 
perak turun 4,8 persen. Pada kuartal I tahun ini, perseroan juga sama sekali tidak menjual bijih bauksit (www.tempo.co, diakses 5 Juni 2014).

Sementara itu, mineral konsentrat milik Freeport dan Newmont belum mendapat izin ekspor dari pemerintah. Mineral konsentrat Freeport dan Newmont yang masih tersimpan tersebut nilainya mencapai US\$ 1,5 miliar, terdiri dari US\$ 450 juta dari Newmont dan US\$ 950 juta dari Freeport (www.gatra.com, diakses 5 Juni 2014). Bea ekspor $20 \%$ dari penerimaan kotor dikurangi royalti membuat profit margin tambang menipis, dari 27$30 \%$ menjadi hanya 7\%. (http://bisnis.liputan6.com, diakses 13 Juni 2014).

Kebijakan pelarangan ekspor mineral mentah telah merugikan perusahaan pertambangan. Guna menekan potensi kerugian, perusahaan pertambangan berusaha melakukan efisiensi. Langkah efisiensi yang telah dilakukan antara lain dengan cara negosiasi dengan para pemasok untuk mendapatkan potongan harga dan menunda proyek-proyek investasi yang dianggap belum terlalu penting. (www.tempo.co, diakses 5 Juni 2014). Perusahaan pertambangan mempercepat pembangunan pabrik pengolahan dan pemurnian. Sementara itu, perusahaan besar melakukan pengambilalihan perusahaan pertambangan lain yang produknya masih dimungkinkan untuk diekspor, meski dengan membayar BK mineral, demi memperoleh pendapatan. Strategi ini dijalankan oleh PT Central Omega Resources, Tbk. Pihak perusahaan mengakui besaran BK sebesar 20 persen di tahun 2014 masih ekonomis (www.majalahequipment.com, diakses 28 Mei 2014). Sementara itu, PT Antam juga akan meningkatkan target penjualan logam mulia (emas), dari hanya 9,3 ton menjadi 13 ton, dan batubara. (www.gatra.com, diakses 5 Juni 2014).

Untuk membangun industri pengolahan dan pemurnian mineral (smelter) dibutuhkan sejumlah persyaratan. Pembangunan pabrik membutuhkan ketersediaan tanah, pasokan energi listrik, sumber daya manusia dan keselarasan dengan kondisi lingkungan. Berkenaan dengan kesiapan pasokan energi listrik, PLN menyatakan bahwa terdapat 3 (tiga) provinsi yang dapat memasok kebutuhan listrik untuk smelter, yaitu Jawa Tengah, Jawa Timur, dan Sulawesi Selatan. Selain pasokan listrik, perusahaan smelter membutuhkan dukungan infrastruktur jalan dan pelabuhan. Selain itu, Industri ini termasuk kategori padat modal.

\section{Dampak Bea Keluar Mineral terhadap \\ Pemerintah}

Nota Keuangan APBN 2014 menyebutkan pendapatan pertambangan minerba dalam RAPBN 2014 ditargetkan sebesar Rp21,3 triliun, meningkat sebesar Rp3,2 triliun atau 17,6 persen bila dibandingkan dengan targetnya dalam APBNP tahun 2013. Peningkatan tersebut terutama didorong oleh pendapatan royalti sebesar Rp3,1 triliun atau 18,1 persen. Sementara itu, pendapatan iuran tetap dalam tahun 2014 ditargetkan sebesar Rp0,8 triliun, atau Rp0,1 triliun lebih tinggi dari targetnya dalam APBNP 2013. Untuk mendukung pencapaian pendapatan pertambangan mineral dan batu bara tersebut, dalam tahun 2014 sasaran produksi pertambangan mineral dan batu bara adalah tercapainya target produksi (a) batubara sebesar 360 juta ton; (b) timah sebesar 95 ribu ton; (c) feronikel sebesar 20 ribu metrik ton; (d) tembaga sebesar 739,8 ton; (e) emas sebesar 73,9 ton; (f) perak sebesar 215,2 ton; dan (g) bijih besi sebesar 1 juta ton.

Nota Keuangan APBN 2014 menyebutkan bahwa realisasi pendapatan BK 2013 atas bijih mineral sebesar Rp6,1 triliun. Pemerintah mengakui bahwa penerimaan $\mathrm{BK}$ akan menurun sebagai konsekuensi larangan melakukan ekspor barang tambang mentah sesuai amanat UU 4/2009. Pendapatan BK atas konsentrat mineral diperkirakan sebesar $8 \%$ dari target penerimaan BK atau sebesar Rp1,6 triliun (Asosiasi Pertambangan Indonesia, diakses 13 Juni 2014).

Sektor pertambangan umum memberikan kontribusi yang besar bagi penerimaan dalam negeri APBN, baik dari sumber perpajakan maupun dari Penerimaan Negara Bukan Pajak (PNBP). Jenis perpajakan yang dimaksud adalah pajak pemerintah pusat dan daerah, yaitu (Kementerian Perindustrian, 2012:23-24): (1) Pajak Pemerintah Pusat dan yang dibagihasilkan, meliputi: (i) Pajak Dividen, (ii) Pajak Penghasilan Badan, (iii) Pajak Penghasilan Perseorangan, (iv) Pajak Penghasilan 23/26/Final, (v) Pajak Pertambahan Nilai, (vi) Pajak Penjualan Barang Mewah, (vii) Pajak Bumi dan Bangunan, (viii) Bea Masuk, (ix) Cukai; (2) Pajak Pemerintah Daerah, meliputi:(i) Pajak Mineral C dan Air/Lumpsum (Kab. Mimika), (ii) Pajak atas Air (Prov. Papua), (iii) Pajak Kendaraan Bermotor/Bea Balik Nama Kendaraan Bermotor, (iv) Pajak Air Bawah Tanah dan Air Permukaan (water levy), (v) Pajak Mineral C; (3) Sedangkan yang termasuk PNBP adalah: (i) Royalti, (ii) Landrent/deadrent, (iii) Provisi Sumber Daya Hutan, (iv) Iuran Kehutanan (Dana Reboisasi).

Sektor energi dan sumber daya mineral memberi kontribusi kepada penerimaan negara melalui komponen Penerimaan Negara Bukan Pajak (PNBP). Kontribusi kepada PNBP tersebut tercermin dari penerimaan SDA dan merupakan yang tertinggi dibandingkan dengan komponen lainnya. (Kementerian Perindustrian, 2012:100). Pembatasan ekspor mineral mentah akan menurunkan penerimaan negara dan daerah. Potensi kehilangan penerimaan negara diperkirakan sebesar $\mathrm{Rp} 20$ triliun, terdiri dari penerimaan pajak $\mathrm{Rp} 6$ triliun dan PNBP yang berasal dari royalti sekitar Rp 14 triliun (Indonesia Finance Today, 18 Maret 2014:6).

Kebijakan pembatasan ekspor mineral akan berdampak pada penerimaan negara sebagai berikut 
(Bank Dunia, 2014:30): (1) Penurunan penerimaan dari BK ekspor mineral mentah (PMK 75/2012), (2) Penerimaan dari BK ekspor konsentrat mineral (PMK 6/2014), tetapi jumlahnya akan semakin menurun seiring peningkatan tarif BK yang semakin tinggi, (3) Penurunan penerimaan royalti (PNBP) mineral mentah, (4) Kenaikan penerimaan royalti (PNBP) dari ekspor konsentrat mineral, (5) Penurunan pajak penghasilan badan sebagai akibat dari penurunan laba dan peningkatan biaya perusahaan.

Kontribusi sektor pertambangan juga dirasakan oleh daerah. Daerah akan menerima Dana Bagi Hasil (DBH) serta penerimaan pajak daerah. Penurunan penerimaan dari sektor pertambangan akan menurunkan alokasi DBH. Bagi pemerintah daerah, penurunan penerimaan PNBP akan menurunkan DBH. Sebagai gambaran pada pertambangan tembaga, berdasarkan PMK 18/2014, alokasi DBH pertambangan umum tahun 2013 untuk Kabupaten Mimika (Papua) dan Kabupaten Sumbawa Barat (Nusa Tenggara Barat) masing-masing sebesar Rp 1.932.218.990,- dan Rp 1.297.191.556,-. Apabila aktivitas penambangan di kedua daerah tersebut berhenti, maka kedua daerah tersebut berpotensi kehilangan penerimaan $\mathrm{DBH}$ dan penerimaan pajak daerah.

Penurunan ekspor ini belum diikuti oleh kemampuan industri pengolahan mineral di dalam negeri sehingga potensi mineral tersebut belum dapat dimanfaatkan untuk menghasilkan keuntungan ekonomi (dijual). Hal ini berdampak pada penurunan aktivitas produksi pertambangan hingga terjadi pemutusan hubungan kerja karyawan dan berkurangnya kegiatan ekonomi di daerah sekitar wilayah pertambangan. Penurunan kegiatan ekspor dan produksi pertambangan mineral yang belum diikuti kemampuan dalam menyerap potensi mineral di dalam negeri ini menurunkan aktivitas ekonomi sehingga menurunkan potensi penerimaan negara dari perpajakan dan PNBP (iuran tetap, royalti) serta penerimaan daerah dalam bentuk pungutan retribusi dan DBH.

\section{SIMPULAN}

Berdasarkan uraian yang telah diuraikan, dapat disimpulkan bahwa:

1. Penetapan BK mineral dalam PMK 6/2014 diperlukan guna memperkuat tujuan kebijakan pengelolaan mineral dalam UU 4/2009, yaitu dalam rangka mendukung peningkatan nilai tambah sumber daya mineral bagi sebesar-besar kemakmuran rakyat secara berkeadilan. Pengenaan BK bertujuan menjamin manfaat pertambangan mineral secara berkelanjutan dan berwawasan lingkungan hidup, serta menjamin tersedianya mineral sebagai bahan baku untuk kebutuhan dalam negeri. Tujuan PMK 6/2014 mendukung arah kebijakan pengelolaan mineral dalam Pasal 3 UU 4/2009, khususnya huruf (b), (c), dan (e). PMK 6/2014 telah menetapkan skema tarif BK yang semakin tinggi sampai dengan tahun 2016 dalam rangka mendorong investor/perusahaan pertambangan melakukan percepatan pembangunan pabrik pengolahan dan pemurnian mineral di dalam negeri.

2. Penetapan BK mineral dalam PMK 6/2014 telah berdampak pada penurunan volume ekspor mineral dan pelemahan aktivitas ekonomi di wilayah sekitar pertambangan. Kondisi ini mengakibatkan penurunan produksi mineral yang diikuti terjadinya rasionalisasi pekerja dan berkurangnya penerimaan negara dari pajak / PNBP pertambangan sehingga berdampak negatif terhadap kesejahteraan masyarakat, khususnya di sekitar wilayah pertambangan. Dalam jangka menengah dan panjang, kebijakan pengenaan BK dalam PMK 6/2014 dapat berdampak positif terhadap perekonomian nasional sepanjang tersedia pabrik pengolahan dan pemurnian mineral.

Saran

Merujuk pada simpulan di atas, dapat diberikan saran sebagai berikut:

1. Guna menumbuhkembangkan perekonomian nasional, selain menerapkan kebijakan kebijakan disinsentif fiskal BK dan insentif fiskal untuk investasi industri hilir pertambangan, pemerintah dapat mempertimbangkan pengembangan potensi ekonomi daerah selain sektor pertambangan, seperti pengembangan sumber daya manusia, modernisasi pertanian, pariwisata, dan lain sebagainya. Hal ini dapat menjadi awal yang baik untuk melakukan transformasi dari perekonomian yang bertumpu pada sektor pertambangan kepada sektor-sektor ekonomi yang lebih produktif dan lebih menjamin pembangunan ekonomi secara berkelanjutan.

2. Pengenaan BK seharusnya didasarkan pada pungutan negara tidak mengganggu pertumbuhan ekonomi, pengentasan kemiskinan, penyediaan lapangan kerja dan pemerataan pendapatan. Memperhatikan potensi dampak pelemahan ekspor mineral terhadap masyarakat, pemerintah dapat memberikan alternatif sumber mata pencaharian baru atau jenis pekerjaan lain yang kiranya dapat mengurangi dampak buruk akibat PHK atau pelemahan aktivitas ekonomi. Pemerintah dapat mempertimbangkan pemberian kebijakan affirmative, seperti bantuan barang kebutuhan pokok dan pelayanan dasar untuk masyarakat dan pekerja, khususnya di sekitar wilayah pertambangan.

\section{DAFTAR PUSTAKA}

A. Buku, jurnal, laporan penelitian

Amir, Hidayat. Economic Impact Analysis of the 2012 
Indonesia Mineral-Export Tax Policy: A CGE Approach. The International Journal of Economic Policy Studies, Volume 8, 2013, h. 1-22.

Badan Pusat Statistik. 2013. Statistik Pertambangan Non Minyak dan Gas Bumi 2010-2012. Jakarta.

Badan Pusat Statistik. Berita Resmi Statistik Nomor 11/02/Th. XII, 16 Februari 2009.

Badan Pusat Statistik. Berita Resmi Statistik Nomor 16/02/Th. XVII, 5 Februari 2014.

Bank Dunia. 2014, Maret. Perkembangan Triwulanan Perekonomian Indonesia: Investasi yang Tak Menentu. Perkembangan Triwulanan Perekonomian Indonesia. The World Bank.

Dewi. 2010. Skripsi: Aspek Hukum Kontrak Karya Dalam Investasi Pertambangan Umum. Fakultas Hukum Universitas Sumatera Utara.

Djamaluddin, H., Meinarni Thamrin, dan Alfajrin Achmad. 2012. Potensi dan Prospek Peningkatan Nilai Tambah Mineral Loga di Indonesia (Suatu Kajian Terhadap Upaya Konservasi Mineral). Prosiding Hasil Penelitian Fakultas Teknik Universitas Hasanuddin Volume 6 (Desember 2012).

Fuad, Noor, dkk. 2004. Dasar-Dasar Keuangan Publik. Jakarta: LPKPAP-Badan Pendidikan dan Pelatihan Keuangan.

Kementerian Perindustrian RI. 2012. Analisis Biaya Manfaat Pelarangan Ekspor Bahan Mentah Minerba dan Dampaknya Terhadap Sektor Industri: Studi Kasus Nikel \& Tembaga. Jakarta.

Komisi Pemberantasan Korupsi. 2013. Laporan Hasil Kajian Sistem Pengelolaan PNBP Mineral dan Batubara. Jakarta.

Mahkamah Konstitusi. Putusan Mahkamah Konstitusi Nomor 58/PUU-VI/2008.

Mahkamah Konstitusi. Putusan Mahkamah Konstitusi Nomor 002/PUU-I/2003.

Purwito, Ali. 2009. Kepabeanan dan Cukai (Pajak Lalu Lintas Barang) Teori dan Aplikasi. Jakarta: Badan Penerbit Fakultas Hukum Universitas Indonesia.

Pusat Data dan Informasi Energi dan Sumber Daya Mineral, Kementerian Energi dan Sumber Daya Mineral. 2012. Kajian Supply Demand Mineral. Jakarta.

Raden, Ince, dkk. 2010. Laporan Penelitian Kajian Dampak Penambangan Batubara Terhadap Pengembangan Sosial Ekonomi dan Lingkungan di Kabupaten Kutai Kartanegara. Jakarta: Badan Penelitian dan Pengembangan Kementerian Dalam Negeri.

B. Perundang-undangan

Undang-Undang Dasar 1945.

Undang-Undang Nomor 10 Tahun 1995 tentang Kepabeanan.

Undang-Undang Nomor 4 Tahun 2009 tentang Pertambangan Mineral dan Batubara.

Peraturan Pemerintah Nomor 55 Tahun 2008 tentang Pengenaan Bea Keluar Terhadap Barang Ekspor.

Peraturan Pemerintah Nomor 23 Tahun 2010 tentang Pelaksanaan Kegiatan Usaha Pertambangan Mineral dan Batubara.

Peraturan Pemerintah Nomor 1 Tahun 2014 tentang
Perubahan Kedua Atas Peraturan Pemerintah Nomor 23 Tahun 2010 tentang Pelaksanaan Kegiatan Usaha Pertambangan Mineral dan Batubara.

Peraturan Menteri Keuangan Nomor 75/PMK.011/2012 tentang Penetapan Barang Ekspor yang Dikenakan Bea Keluar dan Tarif Bea Keluar.

Peraturan Menteri Keuangan Nomor 6/PMK.011/2014 tentang Perubahan Kedua Atas Peraturan Menteri Keuangan Nomor 75/PMK.011/2012 tentang Penetapan Barang Ekspor yang Dikenakan Bea Keluar dan Tarif Bea Keluar.

Peraturan Menteri Energi dan Sumber Daya Mineral Nomor 1 Tahun 2014 tentang Peningkatan Nilai Tambah Mineral Melalui Kegiatan Pengolahan dan Pemurnian Mineral di Dalam Negeri.

Republik Indonesia. Nota Keuangan APBN Tahun 2014.

C. Berita, artikel, dan/atau sumber lain dari internet

Asosiasi Pertambangan Indonesia. Batasan Ekspor Mineral Diperlonggar. http://www.imaapi.com/index.php?option=com_content $\&$ view=ar ticle\&id=1463:batasan-ekspor-mineral-

diperlonggar\&catid=47:medianews\&Itemid $=98 \&$ lang=id. Diakses tanggal 30 Mei 2014.

Asosiasi Pertambangan Indonesia. Perusahaan Tambang Tidak Harus Bangun Smelter. http://www.ima-

api.com/index.php?option=com_content\&view=ar ticle\&id=1070\%3Aperusahaan-tambang-tidakharus-bangun-smelter\&catid=1\%3Aimanews\&Itemid $=86 \&$ lang=en. Diakses tanggal 5 Maret 2014.

Asosiasi Pertambangan Indonesia. Penerimaan Bea Keluar Bisa Turun. http://www.imaapi.com/index.php?option=com_content\&view=ar ticle\&id=1825\%3Apenerimaan-bea-keluar-bisaturun-444\&catid $=47 \% 3$ Amedianews\&Itemid=98\&lang=id. Diakses 13 Juni 2014.

Asosiasi Pengusaha Mineral Indonesia. Pelarangan Ekspor Akibatkan Puluhan Ribu Karyawan Dipecat. http://www.apemindo.com/gallery/81news/media-news/623-pelarangan-eksporakibatkan-puluhan-ribu-karyawan-dipecat. Diakses 13 Juni 2014.

Koran Indonesia Finance Today. 2014, 18 Maret. Larangan Ekspor Mineral Kurangi Penerimaan Negara Rp20 Triliun. hlm. 6.

http://www.gatra.com/ekonomi-1/52846-bea-keluarekspor-mineral-bakal-turun-jadi-5-10.html. Diakses tanggal 22 Mei 2014.

http://bisniskeuangan.kompas.com/read/2014/06/03/170 4236/Ekspor.Mineral.Dilonggarkan.Neraca.Perda gangan.Bakal.Surplus, diakses 5 Juni 2014.

http://www.gatra.com/ekonomi-1/53802-belum-dapatizin-ekspor,-mineral-konsentrat-usd-1,5-miliartertahan.html, diakses tanggal 5 Juni 2014.

http://ekonomi.metrotvnews.com/read/2014/05/05/2384 69/perlambatan-ekonomi-akibat-larangan-ekspormineral-mentah, diakses 17 Juni 2014.

http://nasional.kontan.co.id/news/kadin-akan-ajukan- 
uji-materi-bea-mineral-ke-ma, diunduh tanggal 3 Juni 2014

http://bisnis.news.viva.co.id/news/read/485683-bps-ekspor-mineral-mentah-anjok-70--di-januari, diunduh tanggal 28 Mei 2014.

http://industri.kontan.co.id/news/transportasi-mahaljadi-alasan-mangan-boleh-ekspor, diakses 9 Juni 2014.

http://www.majalahequipment.com/index.php/feature2/ 88-gelombang-phk-di-tambang-mineral. Diakses tanggal 28 Mei 2014.

http://www.tempo.co/read/news/2014/06/02/088581910 /Larangan-Ekspor-Mineral-Antam-Rugi-Rp-272Miliar. Diakses 5 Juni 2014.

http://bisnis.liputan6.com/read/2058736/bea-keluarmineral-gerus-untung-pengusaha-tambang, diakses 13 Juni 2014.

http://www.tempo.co/read/news/2014/03/26/092565592 /Pendapatan-Antam-Tergerus-Larangan-EksporMineral. Diakses 5 Juni 2014.

http://www.presidenri.go.id/index.php/fokus/2013/08/1 6/9309.html, diakses 24 Juni 2014.

Pusat Bahasa Kementerian Pendidikan Nasional. Kamus Besar Bahasa Indonesia. http://pusatbahasa.kemdiknas.go.id/kbbi/index.ph p, diunduh tanggal 26 Mei 2014. 
